\title{
Crisis of Management of Household Waste in Abidjan, The Answer of the Informal Private Precollectors in the Municipality of Yopougon (Côte d'Ivoire)
}

\author{
Adomon Abodou Athanase \\ Institut de Géographie Tropicale, Université Félix Houphouet Boigny, Abidjan, Côte d'Ivoire \\ Email: athanaseadomon@yahoo.fr
}

How to cite this paper: Athanase, A.A. (2016) Crisis of Management of Household Waste in Abidjan, The Answer of the Informal Private Precollectors in the Municipality of Yopougon (Côte d'Ivoire). Journal of Geoscience and Environment Protection, 4, 58-71.

http://dx.doi.org/10.4236/gep.2016.413004

Received: August 8, 2016

Accepted: December 26, 2016

Published: December 29, 2016

Copyright $\odot 2016$ by author and Scientific Research Publishing Inc. This work is licensed under the Creative Commons Attribution International License (CC BY 4.0).

http://creativecommons.org/licenses/by/4.0/

\begin{abstract}
The present contribution aims at helping the Mayors to implement a less expensive and effective system of management of household refuse to Yopougon. Indeed, the incapacity of service providers to be assured the collection of the garbage and the failure of their systems of pre-collection favored the emergence of the informal private precollectors in the municipality of Yopougon. The regularity of the interventions of these new actors, the affordable cost of their services and the living environment daily freed the garbage incites the households to request them because they succeed better where service providers failed. Such an activity will have to be better organized because of supplier employment.
\end{abstract}

\section{Keywords}

Municipality, Informal Private Precollectors, Household Garbage, Yopougon

\section{Introduction}

The African cities, especially the capitals, show unbearable realities: tentacular urban developments, whole districts excluded from urban services, overwhelmed and ineffective municipal teams, urban landscapes marked by piles of garbage, and living environment urban particularly unhealthy [1]. These reports, revelations of the place of waste in the urban development, raise the question of the control of the environmental management by the persons in charge of communities.

The municipalities indeed, are confronted with such realities since 1980 [2]. 
In Abidjan for example, the busiest ways are strewed with a stream of uncontrolled dump sites because of the incompetence of the service provider of collection and in the frequent crises of the sector of management of the garbage which disrupt the mechanisms of collection of waste set up [3]. Yet so far, the problem was seen in financial and technical terms nevertheless the proliferation of uncontrolled dump sites and foul smells keep degrading the environment because of the partial collection of waste, etc. [4]. Today still the degradation of the environment is more and more disturbing in the Ivory Coast urban areas, while service providers responsible for the management of the garbage have difficulty in assuming their responsibility since the end of the post-election crisis of 2011. What's to be done in front of the advanced degradation of the living environment? It is a question through this contribution of reflecting about the appropriate mode of the collection of household waste in a context of acute socioeconomic and financial crisis since the end some crisis comment electoral of April 2011 dans the Ivory Coast municipalities.

She articulates around the responsibility of some and others in the proliferation of household waste; expose the causes of the failure systems of collection previous, described and explicit the action of the informal private precollectors in the circuit of the management of the garbage then clears finally the constraints and the advantages of this form of emergent pre-collection.

Yopougon, bedroom town, is our field of investigation. This is established on a 14.435 hectare surface neighborhood. She is subdivided into 28 districts; understands 16 villages and zones of pronounced and unhealthy precariousness, in which teem plastic bags, packagings of fruit juice, and cans which know an increase in volume [3]. Populated furthermore 1074.543 in 2014 [5] against 688.235 inhabitants in 1998 [6], household waste produced to the everyday life by the populations are more and more important for it.

\section{Method}

The methodological approach leans at first on the synthesis of the documentation relating to the management of household waste in Ivory Coast and somewhere else. Conversations (maintenances) were led in districts SICOGI-SIDECI hire purchase LEM beside 253 head of the household on 12,673 households (houseworks) that is $1 / 50$ of the households (houseworks) [6], requesting regularly the services (departments) of the precollectors, and finally interviews of some informal private precollectors.

The first type of interview consisted in collecting the notices of the heads of the household on the collection of the garbage in their district; on the level of satisfaction of the action of the latter by report the collection of the garbage to the everyday life; to arrest their needs and expectations regarding purification of the living environment; on a possible contribution from them as for the collection of household waste; etc. 
The second type of interview, realized with the precollectors occurring directly or indirectly in the refuse collection, concerned mainly the modus operandi of the latter; their daily route; the relations linking them to the households, other users and the municipal authorities; the mode of their remuneration; the future of their activity; etc.

\section{Results}

\subsection{The Proliferation of Waste and Wild Trash Cans, Shared Responsibility}

The responsibilities of management of household waste are shared between the District of Abidjan and the municipalities since January, 2004 certainly, but this management involves unsuspected responsibilities.

The role of the District is the collection and the elimination of waste, sweeping of the urban ways.

The District in its task puts at the disposal of the municipalities of companies for the collection of garbage (mail N 053/07 DEH of the District of Abidjan) as it is the case for SQUEAKY CLEAN BOR, EHSP, SOROA and Lassire waste services to Yopougon.

Then, there is a municipality which is responsible for the pre-collection, for the transport and for the elimination of household waste correspondingly (law $\mathrm{N}$ 96-766 of October 03rd, 1996 of the code of the environment). This one assures:

1) The pre-collection of the household waste which consists in extracting the garbage of its place direct production and in making it change owner. This stage seems to be neglected by the municipality because the garbage amassed and piled up in border of streets is forwarded with difficulty to the planned sites of discharge.

2) The transport of the collected garbage which consists in extracting the garbage of the place of residence of the inhabitants and in concentrating them in a station of transit before forwarding them to the place of definitive elimination. There also, the municipality has not itself materials adapted to assure this second stage. Generally, it confides the transport of household waste to private companies subjected to a direct or indirect contract of collection and transport of the garbage towards predefined places of elimination. Unfortunately, when the closed of the contract are not respected, the municipality remains powerless for reasons of finance.

3) Finally, the elimination of the collected garbage, the third field of intervention of the municipality, consists of a simple dumping of the garbage in a zone situated in the periphery of the municipality in case to Akouédo. In the practice, the elimination consists of the abandonment of waste in the nature or to burn them. This practice is favorable to the distribution of endemic diseases (typhoid, the malaria, the skin cancer) and of respiratory diseases.

The third level of responsibility concerns the households which ignore or often neglect the minimal rules of hygiene and maintenance of their living envi- 
ronment. Certain households throw the garbage in runoff water. Others put them in bags which they throw in streets while possibilities of elimination of the garbage offer themselves to them [7]: they is store them in trash cans while waiting for the passage of the vehicles of collection; they is empty trash cans once full in safes of garbage installed in precise places by service providers; they is pay precollectors to remove them. Unfortunately, they prefer to get rid of it in ravines, gutters, in the lagoon, on public places considered as free and close to their house (Photo 1) because of the estrangement of the points of collection of waste [8].

Finally, the responsibility of degradation of the living environment falls to the precollectors who work on their own account. The latter, paid to the act by the households get rid of garbage where they can for some when they meet difficulties in the zones of bulkings. Indeed, the wild deposits of garbage in streets and on pieces of waste ground to Yopougon are disturbing: 36\% to Doukouré, $24 \%$ to Niangon and $18 \%$ to Yaoséhi [8]. The questioned households confirmed this concern: $100 \%$ in the district LEM; $84 \%$ in the SIDECI and $68 \%$ in the district SICOGI.

In a general way, $69 \%$ of the questioned heads of the household consider that since 2002, the municipality of Yopougon is very dirty. Indeed, since the release of the military political and civil crisis, we attend neglected progressive operations of cleaning of the city of Abidjan; what favors the accumulation of wild deposits of garbage on public places today. He in follow-up unsightly one landscaped and an increasing degradation of the living conditions of the populations [9] coach the operation "Clean City" committed by the government since 2009 was not able to freed the economic capital and his neighborhood of waste yet. Consequence, the pre-collection, the collection and the evacuation of the garbage establish a major challenge to be at present raised in Abidjan. The reasons are multiple.

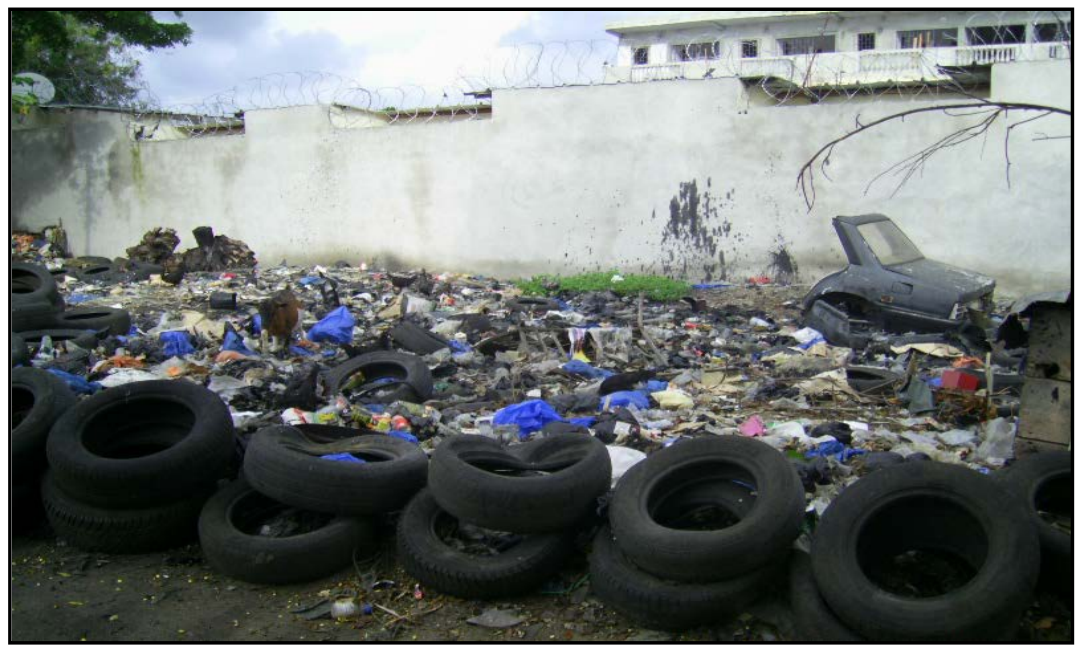

Photo 1. The closeness of a house to Yopougon transformed into garbage dump of household refuse. Photograhpie: Adomon, 2009. 


\subsection{The Reasons of the Failure of Service Providers and Municipal Officers in the Pre-Collection of the Garbage to Yopougon}

As already indicated, the District of Abidjan puts at the disposal of the municipalities, the companies for the collection of garbage, as it is the case of SQUEAKY CLEAN BOR, EHSP, SOROA and Lassire waste services to Yopougon. These companies assure the transport of waste since the centers of bulking up to the center of transfer of discharge of Akouédo or in the center of Technical Burying (CET). Unfortunately, these companies do not assume suitably this task for lack of adequate materials.

Consequence, the collection is only made on along the main ways and in the entrance of the not asphalted suburbs and the villages of the municipality.

This partial management of the urban waste is at the origin of the degradation of the living environment and the environment with enormous consequences on the health of the populations. Indeed, companies just like CLEAN-BOR also intervene in the pre-collection of household waste to Yopougon. They take care of the collection of garbage put down by the users in tubs(ferries, high school diplomas) placed near the big highways, in markets and almost everywhere in municipality. This garbage collected by the trucks of service providers is transported in the discharge of Akouédo.

Unfortunately, the location of tubs in garbage raises problem because few, they are badly distributed on the municipal territory. When they are full, the users put down the garbage on the floor because the other sites of deposit of tubs are taken away from the target households either placed only along the accessible highways.

The failure of service providers to bring the municipal authorities at that time Yopougon to introduce a project of machines motorized since 11 Mars 2003 to make the pre-collection of the garbage (Photo 2) and to meet the needs of populations.

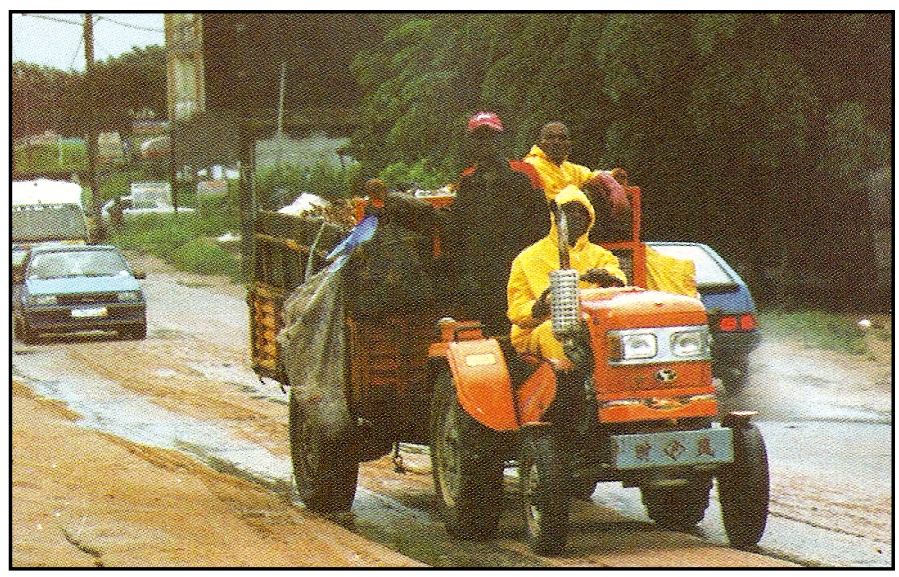

Photo 2. Tractor motorized by the city hall of Yopougon transporting household waste. Credit of photography: Municipalitie of Yopougon, 2007. 
It is about agents of the City hall as we can notice it on the photography 2, which travel the alleys of the accessible districts and proceeding to the pre-collection of household waste. This shape of door-to-door pre-collection is free. Unfortunately, the City hall has only 28 tractors and a center of regroupage staff in the district Mami-Fêtai at 34,600.00 USD for all the municipality. What is insufficient. The economic and financial crisis which crosses the country since 1980 having incidences on the finance of the municipality, this one has difficulty in extending this project in all the districts of the municipality.

Naturally, these authorities resort to the Brigade of the Urban Healthiness (BSU), a state structure which begins operations of healthiness, purification and déguerpissement in the municipalities of Abidjan since 2008 (Photo 3) to help it in the task.

Indeed created on October 04th, 2007 by decree $n^{\circ} 2007 / 587$, the BSU is requested for operations of emergencies by the ANASUR (National Agency of the Urban Healthiness); either for a logistic backup in the fight against the anarchy installations, or for a fight against the nuisances of all kinds and especially for a fight against the illicit occupations of the urban public domain in the city of $\mathrm{Ab}$ idjan.

As we can notice it that it is about municipal officers or about service providers, these structures meet enormous difficulties bound to the insufficiency and to the estrangement of tubs in garbage, in the inaccessibility of machines motorized in the enclosed households, in the irregularity of transfer of the garbage once the filled tubs, etc. anything which engenders foyers of pollution.

\subsection{The Appearance of the Informal Private Precollectors in the Circuit of the Collection of the Garbage to Yopougon}

In front of the failure of service providers and the municipal officers, the new actors set up a mechanism of pre-collection which integrates a financial contribution on behalf of the households and the users against the service of collection of garbage to Yopougon. It is about precollectors of garbage acting upstream by hawking. These independent precollectors subdivided the municipality of Yopougon into eight zones of bulkings of pre-collected (Figure 1).

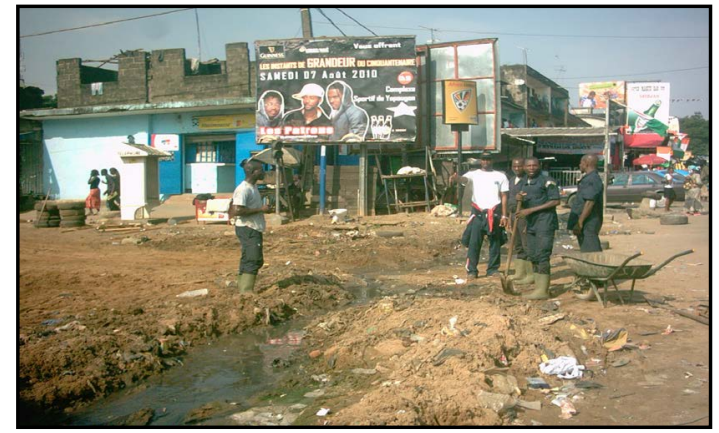

Photo 3. The brigade of healthiness in height sanitation works at the level of the ex-street princess to Yopougon. Photography: Adomon, August, 2010. 


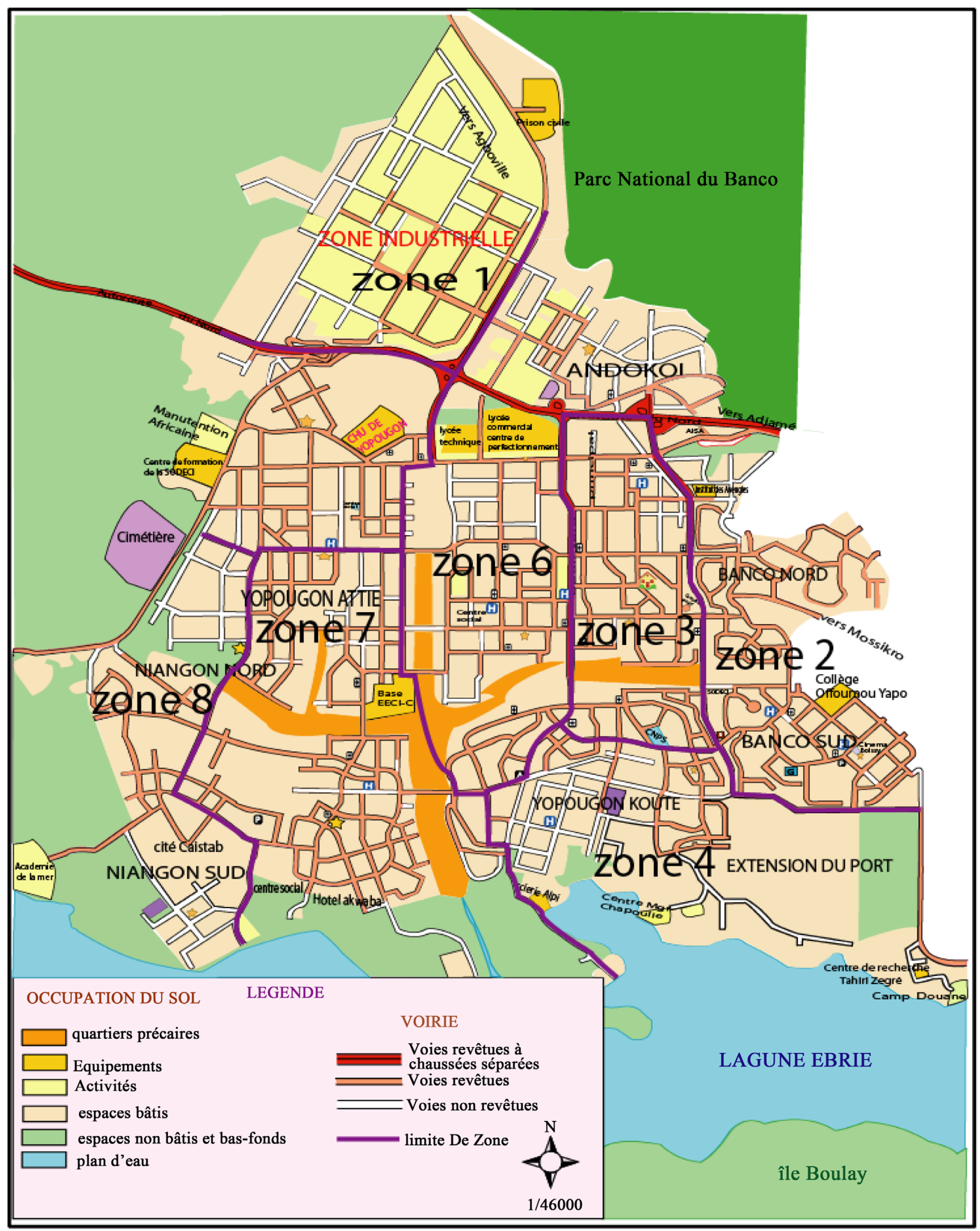

Figure 1. Identification of the zones of bulking of the garbage housewives to Yopougon. Source: center of mapping and remote detection (CCT), on 2003. Realization: Ané, 2013. 
Every zone, equipped in site of bulkings is the falling point of the garbage precollected with the households. Every site has 2 safes: one of the $20 \mathrm{~m}^{3}$ and the second of $7 \mathrm{~m}^{3}$. The zone of bulking is piloted by a leader who has under his responsibility of the leaders of deposits who manage each a group of precollectors. There are 27 functional zones of bulking on 35 that counts the municipality. The leaders of deposit rent sites with villages or at private individuals in 17.30 USD/month.

On a site of bulking, we meet fourcheurs, another link of the chain of precollection. The latter collect the garbage cross-posted by the precollectors with a fork and fill safes. Every fourcheur perceives by safe 3.98 USD a day. On the site we also meet sweepers who maintain the deposit, the mechanics who take care of tractors and especially of sorters (Photo 4) [10] which are loaded of the recovery of the glass bottles or the plastic, the metal, etc.

We also have garbage men who intervene in the circuit. They are as if to asking to help the tractor drivers during the missions of the pre-collection of garbage in districts. They are generally carters or brouettiers (Photo 5) which make the door-to-door pre-collection.

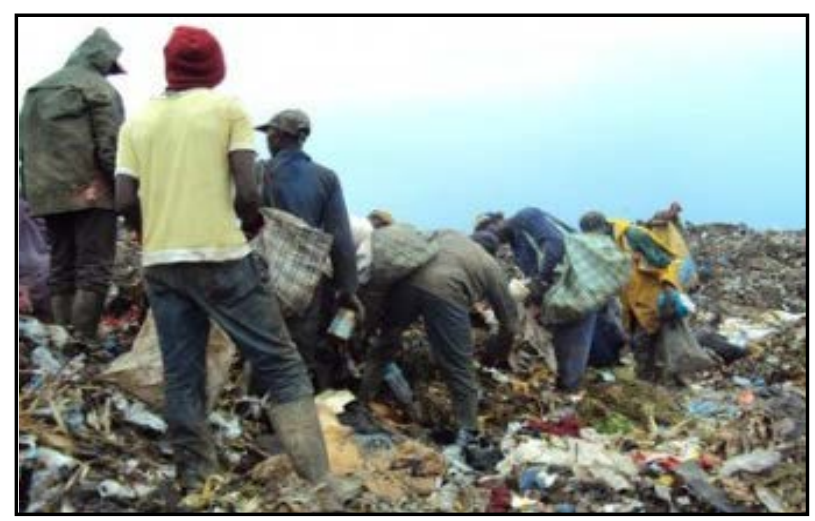

Photo 4 . The sorters in height activity in a center of bulking. Credit of photography: Boni Adon, 2012.

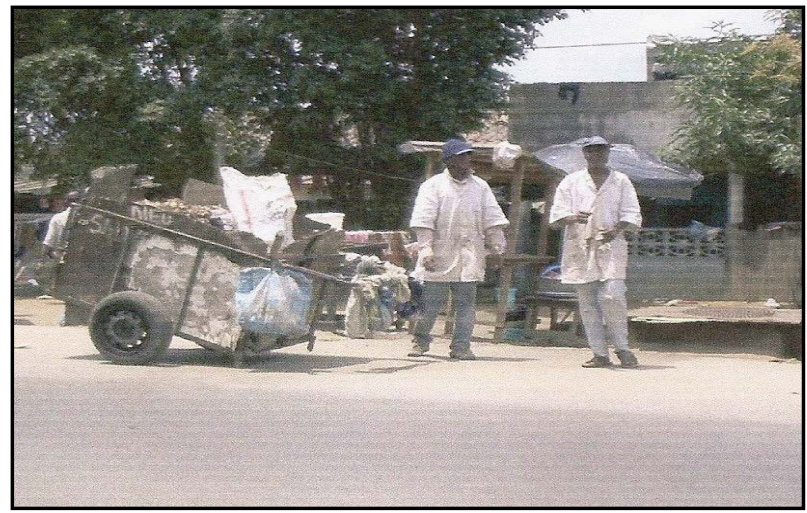

Photo 5. Precollectors deprived of household waste in service with their cart (wottro). Credit of photography: Coulibaly Sita, 2006. 
They use very often of the equipment of fortune as it is the case on the photography 5: a cart in two or three wheels with human drive, wheelbarrows, shovels, rakes and forks, a scarf a blouse for some and rarely gloves.

Contrary to companies CLEAN Lassire-Déchet-Service which are bound to the City hall or to the District by a contract, these independent precollectors practise their activity in the illegality, collaborate little with the municipal authorities and are in the informal for the greater part, where from the naming of informal private precollectors. It is for the most part of the volunteers, the pupils or still of students in vacancy that do not want to stand idly by, but also removed from school, persons at a loose end or unemployed which make of this activity a job(business) full-time in spite of the risks.

An informal private precollector begins the day between 4 and 5 o'clock in the morning. Gloves in hands, holding a rake or a stick, wearing boots or not and dragging its cart, it hawks in his zone of operation to get back the garbage of the households.

The collected garbage is then transported until the centers of bulking where are installed safes intended to welcome them generally. Safes belong to companies of collection which have contracts of concession with the city hall or with the District of Abidjan. These companies are responsible for forwarding them in the discharge of Akouédo and are paid in 3000F Cfa by the tonnage of garbage transported according to the direction of the Environment of the District of Abidjan [11]. Besides the informal private precollectors, municipal officers and service providers intervene in the pre-collection of garbage to Yopougon.

\subsection{Informal Private Precollectors Very Requested by the Households to Yopougon}

The pre-collection very close is a old practice in Abidjan since 1991 when the industrial society of the African automobile transport concessionary (SITAF) of period, presented failures [3]. Two categories of households request the service of the informal private precollectors (Table 1).

The questioned households are satisfied $18 \%$ to Yaoséhi; $100 \%$ to LEM; $84 \%$ to SIDECI and $68 \%$ to SICOGI. These households justify their choice by the regularity of the services, the maintenance daily the immediate living environment and the cleanup of the environment in a constant way. Although this shape of pre-collection very close requires a financial contribution on behalf of

Table 1. The types of households who request the precollectors deprived to Yopougon.

\begin{tabular}{ccc}
\hline Type of households & Value cash & Frequency of collection \\
\hline Subscribed households & $1.7-2.55$ USD/Month & Every day \\
Not subscribed households & $\begin{array}{c}0.09-0.17 \text { USD/Days } \\
\text { according to the district }\end{array}$ & Every day except Sunday \\
\hline
\end{tabular}

Source: our inquiries, in November, 2010 (District Sideci, Sicogi, LEM, Yaoséhi). 
the households, it is appreciated by $67 \%$ of the investigated heads of the household who consider that the latter succeed better where service providers failed, because their intervention strengthens the rate for cover and for removal of household waste, where from their satisfaction.

However, approximately $33 \%$ of the heads of the household estimate the cost is with difficulty bearable. These would opt according to Sané [12] for the garbage dump in streets, alleys and on the pieces of waste ground of districts when trash cans put at their disposal by service providers are full. It is in this context that Ané [13] can assert that to Yopougon the door-to-door domiciliary pre-collection turns out to suit in consideration to the context of generalized difficult economic crisis.

\section{Discussion}

\subsection{The Private Pre-Collection, an Informal Activity at Risk but Generator of Employment}

The law N 96-766 of October 3rd, 1996 carrying code of the environment in Côte d'Ivoire [14] stipulates in its article 69: "the State and the local authorities have to watch the creation, the preservation and the maintenance of the green spaces". However, this measure can be the object of a concession provided that local authorities make a commitment to develop action plans and to organize emergency plans in all the domains to protect the environment (art 71). Unfortunately, the informal private precollectors practise their activity without any prior authorization on the territory primary school of Yopougon. De facto, they enter unfair and illegal competition against the service providers which they are subjected to exercise books of responsibility either with the municipality, or with the District. Such a fraudulent practice exposes these actors to enormous risks:

-Art 100: the promoter of any company proceeding to wild deposits is punished for a fine from 1730.00 to $51,900.00$ USD and for a detention of three months or for one of these two punishments only.

Indeed, informal private precollectors are guilty of such act when the already put down garbage did not remove at the level of the sites of bulkings where takes place the unloading of the collected garbage. In this case, the young local residents of the zones of bulkings require a sum by unloading which varies between 0.35 and 0.87 USD. Certain precollectors who refuse to pay, cross-post the garbage pre-collected on squares, in idle places or sometimes in ring peripheral of districts. What in the long run entraine a proliferation of wild deposits. If it turns out that an acting that way precollector detained an authorization to practice this one can be suspended for a period of at least two years. What is improbable because no precollector possesses it.

-Even if the "willingness to pay" suffers from no doubt on behalf of the households for services provided for the purification of their living environment [14], certain districts are with difficulty accessible(approachable) by the wheel- 
barrows of the precollectors of garbage because of the narrow-mindedness of streets and those always filled with waters.

Yet when districts possess accessible streets by the precollectors and the motorized tractors these are less explained to the anarchy deposits of garbage. Should the opposite occur explains a customer: "This garbage is piled up by the sellers until the trucks of collection pick them up. Unfortunately, it takes time.” [15].

-Customers do not still respect the appointments when comes the hour to pay the service. Certain owners of scrublands, restaurants, or hostesses, refuse to pay. This refusal of the fatal consequences on the monthly income which becomes unstable and prevents some from realizing economies.

-The activity is considered little developing by the populations because of the lack of sanitary trainings, the non-existence of a social guarantee and a sanitary security, but especially because of the painful working conditions, the unforeseen sick leaves. So many factors limit the contractualization of the actors of this job with the households and the municipality.

-The monthly maintenance of the cart (wottro) establishes a serious handicap because every month it is necessary to replace tires in 2.60 USD at least because of flats regular. And occasional way every tour to the vulcanisateur costs 0.43 USD.

Dune general way, the informal private precollectors are unanimous that their job entails enormous risks but nevertheless he allows them to meet their monthly needs. Well this activity is generative of employment.

Indeed, a study carried out by the Ministry of the economic infrastructures in 2009 within the framework of "the operation clean city, lot 3: Yopougon and Songon final report from February till June" [13] allows to identify the participants in the process of the pre-collection on every site of bulking with Yopougon (Table 2).

As we can arrest it, 466 people intervene in the process of the pre-collection on a site of bulking with a carters' strong proportion and brouettiers (70\%); (12\%) fourcheurs and (9\%) leaders of deposits. By taking into account 27 functional sites, we have all in all 12,582 people organized in associations, in advice of districts, in committees of healthiness or in individual carters. It is obvious this sector is an appearance of bread job for every individual investigate employment because it requires no diploma to work as informal private precollectors.

The remuneration depends on the district, of the number of customers and especially the importance of the garbage assert certain actors. Indeed, the price fixed for the collection of the garbage of a restaurant or scrubland is not the same that that of the household waste of a foyer, and the amount of the service is payable either at the end of the week or of the month, or in a daily way. So thus every precollector defines his method of payment in agreement with the customer. Some accept 1.73 USD a month to empty trash cans, while others require 
Table 2. Typology of the actors of the pre-collection at the level of a deposit.

\begin{tabular}{|c|c|c|}
\hline Actors & Function & Counts \\
\hline Leader of deposit & $\begin{array}{l}\text { In its owner's quality of the deposit, } \\
\text { he coordinates the activities which take place there. }\end{array}$ & 40 \\
\hline Clerks & $\begin{array}{l}\text { Supervised by the Leader of deposit, he is in charge of noting } \\
\text { the working time of the various speakers with the aim } \\
\text { of their remuneration. At present, he does not exist on the } \\
\text { deposits because of the financial crisis of the sector there. }\end{array}$ & 0 \\
\hline $\begin{array}{l}\text { Fourcheur } \\
\text { provided with a fork }\end{array}$ & He is in charge of putting waste paid on the floor into tubs. & 55 \\
\hline Sweeper & He assures the maintenance of the deposit. & 11 \\
\hline Sorter & $\begin{array}{l}\text { He proceeds to the recovery of certain types of object } \\
\text { in waste (glass or plastic bottle, metal, etc.) }\end{array}$ & 3 \\
\hline $\begin{array}{l}\text { Carter/Brouettier } \\
\text { equipped with cart } \\
\text { or wheelbarrow }\end{array}$ & $\begin{array}{l}\text { He collects waste in the households to } \\
\text { return them to the deposit. }\end{array}$ & 321 \\
\hline Tractor driver (Driver) & $\begin{array}{l}\text { He assures the management and the conduct of the tractor in } \\
\text { the various districts to collect waste to supply the deposit. }\end{array}$ & 10 \\
\hline Garbage man & He helps the tractor driver during the missions of collection. & 14 \\
\hline \multirow[t]{2}{*}{ Mechanic } & He assures the maintenance of tractors. & 3 \\
\hline & Total & 466 \\
\hline
\end{tabular}

Source: Ministry of the economic infrastructures, 2009. "The operation clean city, lot 3: Yopougon and Songon final report from February till June" in Ané [13].

2.60 USD when the barrel is too big. Others else prefer to get back the garbage in 3.46 USD payable on every Saturday at certain storekeepers.

"Every month end, I cash 1.73 USD by house. As for scrublands and restaurants, they pay me each 0.17 USD a day, what returns to 5.19 USD a month" asserts N. M, precollector of household waste in the municipality of Yopougon in the district Roof-red [11]. Just like him, D. B, who recovers every month end 69.20 or 95.15 USD considers that this activity allows him to deal with its monthly responsibilities according to these words:

"I save at the moment. And when I shall have gathered the sum of 865.00 USD, I am going to open my workroom and to exercise my real profession dressmaker" [11], similar for D. B who dreams to save the sum of 432.50 USD to buy to himself a machine to embroider and to exercise its job by embroiderer.

\subsection{How to Register the Pre-Collection Very Close in a Dynamics of Sustainable Management}

The removal of household waste is "the most municipal" urban services which involves the responsibility of the Mayors and their credibility [16]. Yet the municipalities are lacking financial means and cannot offer themselves the technical solutions of industrialized countries. On the other hand they arrange potentialities and not insignificant local assets, which can allow to limit the fatal effects of a badly directed management of garbage. The informal private precollectors in 
the circuit of the management of the garbage are an approach to be explored to organize and to professionalize this activity, which supposes:

1) Un change in the mode to make, which imposes the learning of a technical and institutional "know-how" to all the actors in the pre-collection of the garbage.

2) To make oneself, make-make or check. The municipality can assure a role of client of a minimal urban service in the management of household waste. For that purpose, the municipality can choose:

-To realize herself in direct state control or by a municipal public body the pre-collection as is the case to Yopougon with the motorized tractors;

-To make do by delegation, concession, lease (procurement with specifications) or by a service contract (for example, a subcontract of a part of the service). But this form of practice did not give convincing results yet at the moment. It is advisable to the widened to the informal private precollectors;

-Confine to exercise a role of control of the activity of the private operators by promulgating sanitary standards, conditions of exercise, regulations of public health. It is at this level that the municipality is the most expected in the face of the rise of the phenomenon of the informal private precollectors. Yet, these standards and regulations, for their establishment or their renovation, is the fact of the services of the State far from the municipal ground [4].

After all to register the pre-collection of the garbage in a dynamics of sustainable management [1]; [4]; [14] and [16]; it will be necessary inevitably:

1) Establish a compulsory fee taken directly with the households because a fringe of the population prefers the collection by voluntary contribution by report the containers of garbage dump in districts.

2) Improve then the transport and the elimination of waste.

3) Any activity of collection of garbage will have to take into account the purification and the drainage of rainwaters and some waste water.

\section{Conclusion}

The removal of the garbage is a task which falls firstly to the municipality. It is necessary thus of the adequate material, the diligent and effective staff but especially the politics of refuse processing. What requires enormous financial means on behalf of the municipality of Yopougon. In front of the failure of service providers committed by the District of Abidjan to assure the collection and the refuse collection Yopougon, the informal private precollectors seem to be more effective and appreciated by the households in their actions. However, the tasks must have left between these and of the service providers committed by the District to avoid possible conflicts of jurisdiction.

\section{References}

[1] Thu, T. (1998) For an Efficient Management of Waste in the African Cities: The 
Transfers to be Driven, in the Exercise Books of Municipal Development (PDM) No. 1 in January. Partnership for the Municipal Development (PDM), Cotonou, 59 p.

[2] Adomon. A.A. (2015) Assessment of the Decentralization Policy in Côte d'Ivoire: Case of the Municipalities of Alépé, Taabo and Yopougon. Unique Thesis of Doctorate of Geography, Institute of Tropical Geography (IGT), Félix Houphouët Boigny University, Abidjan, 343 p.

[3] Attahi, K. (2001) Abidjan, Côte d'Ivoire, in the Management of Urban Waste: Solutions for Africa. Supervised by Adepoju G. Onibokun, Publishing Karthala and CRDI, Cotonou, 240 p. Reprimand 2, 16-51.

[4] Sané, Y. (2002) The Waste Management in Abidjan: A Recurring Problem and Apparently without Solution. AJEAM/FUMED on 2002, Flight 4, No. 1, 13-22.

[5] General Inventory of the Population and the Housing Environment of 2014.

[6] General Inventory of the Population and the Housing Environment of 1998.

[7] Adepoju, G. and Kumuyi, A.J. (2001) Ibadan, Nigeria, in the Management of Urban Waste: Solutions for Africa. Supervised by Adepoju G. Onibokun, In: Francophone West Africa; Ibadan, Nigeria, in Anglophone West Africa. Chapters 2-5, Contain Analyses of the Waste-Management Systems and Approaches in the Four Key African Cities. International Development Research Centre (IDRC), Abidjan, 240 p. Reprimand 3, 70-107.

[8] Kouassi, D., et al. (2008) Analysis of the Situation of the Sanitary Environment of Districts Disadvantaged in the Urban Fabric of Yopougon in Abidjan, Ivory Coast. Vertigo-La Seen Again (Revised) in Sciences of the (On-Line) Environment, on 2008, Volume 8, Number 3.

[9] Bouquet, C. and Kassi, I. (2014) "Leave" to Reconquer the Public Place in Abidjan. The (Online) Political Space. http://espacepolitique.revues.org/2963

[10] Boni, A. (2012) Management of the Garbage: Every Municipality of Côte d'Ivoire Has to Have Its Own Dump.

http://www.ivoiregion.net/index.php/dossier/251-gestion-et-valorisation-des-deche ts-chaque-commune-de-cote-divoire-doit-avoir-sa-propre

[11] Wandji, C. (2007) Pre-collection of Waste-Koumassi, Marcory, Yopougon-The Young People Earn the Bread in Household Waste. Intelligent of Abidjan of June 14th, 2007. In Kofi Net. www.koffi.net/koffi/actualites-par-date

[12] Sané, Y. (1999) A City in the Face of Its Waste: A Problem of the Pollution Has Abidjan (Côte d'Ivoire). Doctoral Thesis, Laval University, Quebec, 290 p.

[13] Ané, J. (2013) Municipal Actions and Urbanization of Yopougon. Unique Thesis of Doctorate of Geography, Institute of Tropical Geography (IGT), Félix Houphouët Boigny de Cocody University, Abidjan, 359 p.

[14] Ministry of the Environment of Côte d'Ivoire (1996) The White Paper of the Environment of Côte d'Ivoire. National Plan of Action for the Environment (PNAE) on 1996-2010, 255 p.

[15] Djédjé, J. (2014) Return of the Garbage in Our Municipalities: How to End the Insalubrity in Abidjan? The New Weekly Consumer No. 102 of November 10th, 2014. http://225.ci/cote-d-ivoire/actualites/journal/528/year/2014

[16] Thu, T. (2004) Another Possible Approach of the Urban Purification, in Sustainable Management of Waste and Urban Purification. 19-45. Partnership for the Municipal Development (PDM) Printed by IMP (Medical Educational Institute) Graphic, Cosne-sur-Loire, $192 \mathrm{p}$. 
Submit or recommend next manuscript to SCIRP and we will provide best service for you:

Accepting pre-submission inquiries through Email, Facebook, LinkedIn, Twitter, etc. A wide selection of journals (inclusive of 9 subjects, more than 200 journals)

Providing 24-hour high-quality service

User-friendly online submission system

Fair and swift peer-review system

Efficient typesetting and proofreading procedure

Display of the result of downloads and visits, as well as the number of cited articles

Maximum dissemination of your research work

Submit your manuscript at: http://papersubmission.scirp.org/

Or contact gep@scirp.org 